DOI 10.4467/12332135KRA.21.012.14691

\title{
Wystawa „Rząd na emigracji, kancelaria poza krajem. Materiały związane z działalnością Rządu Ukraińskiej Republiki Ludowej w Tarnowie w latach 1917-1922 ze zbiorów Archiwum Narodowego w Krakowie"
}

W dniach 16-17 września 2021 r. w Krakowie odbyła się konferencja „Archiwa ponadnarodowe" współorganizowana przez Uniwersytet Pedagogiczny w Krakowie oraz Archiwum Narodowe w Krakowie. Patronat nad tym wydarzeniem objął Naczelny Dyrektor Archiwów Państwowych dr Paweł Pietrzyk. Z uwagi na temat konferencji Archiwum Narodowe w Krakowie przygotowało wystawę towarzyszącą temu wydarzeniu, a prezentującą przechowywany w zbiorach własnych zbiór ukrainików. Materiały związane z działalnością rządu Ukraińskiej Republiki Ludowej w Tarnowie z lat 1917-1922 zaprezentowano na 16 planszach, przedstawiając zarówno niezwykle ciekawą historię zbioru, jak i różnorodność przechowywanych archiwaliów.

W 1917 r. na fali ruchów niepodległościowych w czasie I wojny światowej na Ukrainie doszło do powołania rządu i podjęcia walki o suwerenność. W 1920 r. wojska Ukraińskiej Republiki Ludowej uległy kontrofensywie Armii Czerwonej. W obliczu klęski działań niepodległościowych na terenie Ukrainy podjęto decyzję o ewakuacji do Polski. Rozpoczynał się długi okres emigracyjnej tułaczki. Do Tarnowa dotarli ukraińscy żołnierze, za nimi ok. 1200 osób reprezentujących władze URL. Tarnów okrzyknięto pierwszą ,stolicą” emigracyjnych władz Ukrainy. Pomimo iż już w 1922 r. Ukraińcy zadecydowali o wyjeździe z Tarnowa, tu właśnie pozostała diaspora ukraińska, tu dalej funkcjonowały niektóre instytucje ukraińskie, a po latach w tym właśnie mieście utworzono tzw. Muzeum Ukraińskie, w którym przechowywano wytworzone przez kolejne rządy dokumenty. Tak było aż do wybuchu II wojny światowej.

W czasie wojny Niemcy zarekwirowali ukraińskie zbiory i w 1942 r. przewieźli je do Archiwum Państwowego w Krakowie. Tutaj rozpoczęto ich porządkowanie i ewidencjonowanie. W pracach uczestniczyli krakowscy archiwiści z dr. Włodzimierzem Budką, kierownikiem Archiwum Państwowego w Krakowie na czele oraz Władimirem Maciakiem - archiwistą ze Lwowa, sprowadzonym przez Niemców specjalnie do pomocy przy ukraińskich archiwaliach. Zaraz po zakończeniu działań wojennych częściowo opracowane zbiory zostały ponownie zarekwirowane - tym razem przez Armię Czerwoną - i wywiezione do Związku Radzieckiego. Do dzisiaj historycy ukraińscy nie znają miejsca przechowywania większości z nich. W Krakowie pozostała część materiałów wydzielonych w czasie porządkowania, m.in. druki ulotne i zbiór pieczęci oraz ukraińskie banknoty, niemające już wtedy żadnej siły nabywczej. 
Po wojnie resztka pozostałych w Krakowie archiwaliów ukraińskich nie doczekała się szybko zainteresowania. Czas nie sprzyjał zwłaszcza wpisywaniu tego typu akt do ewidencji archiwalnej. Raczej pozostawiano je poza oficjalnymi inwentarzami - z uwagi na obawy o ich dalszą ,rewindykację” przez organy bezpieczeństwa państwowego i wywiezienie do ZSRR. Dopiero po 1989 r., po upadku komunizmu w Polsce, przystąpiono do porządkowania zbioru. Obecnie cieszy się on dużym zainteresowaniem użytkowników, zwłaszcza badaczy ukraińskich.

$\mathrm{Na}$ wystawie zaprezentowano bardzo ciekawą historię ukraińskich zbiorów, pokazując także ich różnorodność, podkreślając rolę miasta Tarnowa - niezwykle ważnego miejsca związanego z emigracyjnym rządem ukraińskim. Bardzo cenny jest zbiór pieczęci i stempli ukraińskich rządów - liczący ok. 160 sztuk. To unikalna kolekcja z dwóch powodów: po pierwsze wyjątkowa jest jej wielkość - Ukraina posiada w swoich zbiorach zaledwie ok. 30 pieczęci z tego czasu, po drugie sam fakt jej zachowania, gdyż w zbiorach archiwalnych pozostawia się tylko najważniejsze pieczęci i zaledwie odciski używanych pieczątek i stempli.

Największą część zbioru Materiałów związanych z działalnością Rządu Ukraińskiej Republiki Ludowej w Tarnowie stanowią banknoty ukraińskie wydawane od 1917 aż do 1919 r. Te z lat 1918-1919 r. zachowane są w bankowym stanie. Oryginalnie zapakowane paczki banknotów dotrwały do dzisiejszych czasów - ułożone są jak po druku seriami i numerami, w plikach po 100 i paczkach po 1000 banknotów. Zdecydowana ich część jest oryginalnie zapakowana w pakiety lub pliki. Większość banknotów posiada oryginalne banderole - do dziś widnieją na nich informacje o zawartości pliku oraz podpis osoby czy osób liczących i pakujących banknoty. Krakowscy archiwiści dostrzegli wartość takich zapisów - banknoty przeliczono bez niszczenia, usuwania czy rozcinania oryginalnych notatek, banderol i zapisów. Dzięki temu możemy dziś pokazać, jak wyglądała bankowa kancelaria Ukrainy ponad 100 lat temu.

Na wystawie zaprezentowano także pierwszy ukraiński banknot wydany w 1917 r. - co niezwykle rzadko się zdarza - aż czterojęzyczny. Jest to banknot o nominale 100 karbowańców, a słowo nominał zapisano w języku ukraińskim (na awersie) oraz rosyjskim, polskim i hebrajskim (na rewersie banknotu). To piękny przykład poszanowania wszystkich żyjących na terenie Ukrainy nacji, a w kontekście konferencji - piękny przykład wdrożonej w życie idei ponadnarodowości. Oprócz kompletu banknotów nowe państwo ukraińskie potrzebowało także całego zestawu papierów wartościowych, właściwych dla funkcjonowania m.in. skarbu, kancelarii, poczty. Zaprojektowane zostały koperty do korespondencji urzędowej z kasowanym znaczkiem, komplet znaczków pocztowych o różnych nominałach i obligacje skarbowe $\mathrm{z}$ kuponami - te materiały także zostały zaprezentowane na wystawie.

Na kolejnych planszach pokazano inne archiwalia przechowywane w zbiorze. To m.in. niewielka ilość dokumentów, np. projekty pierwszej konstytucji Ukrainy czy statut Ministerstwa Spraw Zagranicznych. Warto wspomnieć, że podczas porządkowania dokumentów w czasie okupacji, w trakcie rozsegregowywania akt na poszczególne ministerstwa i instytucje, wydzielono - co jest zwykłą praktyką archiwalną - dużą ilość czystych, nieużywanych formularzy i dedykowanych teczek z nadrukami. Materiały te przeznaczono na makulaturę ze świadomością zachowania kompletnych akt ukraińskich. Czas wojny zmu- 
szał jednak do oszczędności i dlatego formularzy używano z drugiej strony jako materiału piśmiennego - służyły jako brudnopisy pism, sporządzano sprawozdania archiwistów, teczki wykorzystywano jako obwoluty pism. Tym samym część akt registratury Archiwum Państwowego w Krakowie z lat okupacji, a szczególnie z lat 1942-1944 (w tym okresie intensywnie porządkowano akta ukraińskie), została sporządzona na drugiej, pustej stronie tych druków.

Na wystawie zaprezentowano także wydawnictwa rządów ukraińskich - książki i broszury publikowane w kilku językach, a dotyczące historii i ustroju państwa, ale także tomiki ukraińskiej poezji. W niedużej części ocalałych akt zachował się mały albumik z fotografiami i kartami pocztowymi. Znajdują się w nim pozowane fotografie żołnierzy ukraińskich oraz karty pocztowe posyłane z Tarnowa do rodzin na Ukrainie. W zbiorze przechowywane są także karty pocztowe z logo Czerwonego Krzyża - to odpowiedzi tej instytucji na zapytania dotyczące poszukiwań zaginionych w czasie działań wojennych ukraińskich żołnierzy. Niewielki zbiór prezentowanych na wystawie pamiątek żołnierskich dopełnia garść zaśniedziałych i nieco zardzewiałych guzików od munduru - z ukraińskim tryzubem.

Wystawa była prezentowana w hallu nowego budynku Archiwum Narodowego w Krakowie przy ul. Rakowickiej 22E w dniach 16 września - 6 listopada 2021 r. Autorką wystawy jest Iwona Fischer, kierownik Oddziału IV (akt najnowszych), w którego zasobie znajduje się zbiór Materiały związane z działalnością Rządu Ukraińskiej Republiki Ludowej w Tarnowie. W dniu 16 września 2021 r. wystawę obejrzeli uczestnicy konferencji „Archiwa ponadnarodowe”, zwiedzając także nowy budynek Archiwum Narodowego w Krakowie.

Iwona Fischer

Archiwum Narodowe w Krakowie 